\title{
Apakah Classification Shifting Memoderasi Pengaruh Good Corporate Governance terhadap Corporate Social Responsibility Pada Perusahaan Manufaktur yang Terdaftar di BEI?
}

\author{
Ina Mutmainah* \\ * Institut Agama Islam Negeri Pekalongan \\ Program Studi Akuntansi Syariah \\ Jalan Kusuma Bangsa No. 9 Pekalongan, Jawa Tengah 51114, Indonesia \\ E-mail: ina.mutmainah@iainpekalongan.ac.id
}

\begin{abstract}
Abstrak
Penelitian ini bertujuan untuk mengetahui pengaruh good corporate governance terhadap pengungkapan CSR yang dimoderasi oleh manajemen laba. Penelitian ini menggunakan data sekunder dari perusahaan manufaktur yang terdaftar di Bursa Efek Indonesia untuk periode 2014-2018. Teknik pengambilaan sampel dalam penelitian ini adalah purposive sampling, kemudian analisis data menggunakan uji regresi moderasi dengan pengujian selisih mutlak. Hasil penelitian ini menunjukkan bahwa kepemilikan institusional, dan komisaris independen tidak berpengaruh signifikan terhadap pengungkapan CSR, sedangkan komite audit memiliki efek positif terhadap pengungkapan CSR. Selain itu, manajemen laba memperkuat pengaruh positif kepemilikan institusional terhadap pengungkapan CSR, dan memperkuat pengaruh negatif komite audit terhadap pengungkapan CSR. Namun, manajemen laba tidak memoderasi komisaris independen terhadap pengungkapan CSR. Hasil penelitian ini memberikan gambaran bahan evaluasi kinerja bagi perusahaan manufaktur dan pihak-pihak terkait pencapaian good corporate governance dalam melakukan pengawasan terhadap aktivitas manajemen laba dan pengungkapan CSR.
\end{abstract}

Kata kunci: CSR, Kepemilikan Institusional, Komisaris Independen, Komite Audit, Classification Shifting

\begin{abstract}
This study aims to determine the effect of good corporate governance on CSR disclosure moderated by earning management. This study used secondary data from manufacturing companies on the Indonesia Stock Exchange during 2014-2018. Data were garnered through purposive sampling and analyzed by employing the absolute difference of moderation test. Research findings expose that good corporate governance, i.e. institutional ownership and independent commissioners, had no significant effect on CSR disclosure, while audit committees gave a positive effect on CSR disclosure. Earning management, likewise, strengthened the positive influence of the institutional ownership on CSR disclosure and the negative influence of the audit committee on CSR disclosure. Nevertheless, earning management failed to moderate the role of independent commissioners on CSR disclosure. The study promotes the portrayal of performance evaluation for manufacturing companies and stakeholders to establish good corporate governance in controlling practices of earning management and CSR disclosure.
\end{abstract}

Keywords: CSR, Institutional Ownership, Independent Board, Audit Committee, Classification Shifting

\section{Pendahuluan}

Kepedulian perusahaan dalam mengutamakan kepentingan stakeholder selaras dengan perkembangan corporate social responsibility dewasa ini. [C] berisi tentang CSR bahwa perusahaan diharuskan untuk melaksanakan tanggung jawab terhadap sosial dan lingkungnya. Dengan adanya keterbukaan pasar dan teknologi informasi yang berkembang semakin pesat menuntut perusahaan dalam melaporkan tanggung jawab sosialnya harus transparan. [S] tentang penyampaian Laporan Tahunan Emiten atau Perusahaan Publik menyatakan bahwa perusahaan harus melaporkan aktivitas CSR yang telah dilakukan dengan memberikan informasi berkaitan aktivitas dan biaya. 
Laporan keuangan jenis voluntary disclosure didalamnya tertuang pengungkapan CSR sebagai bentuk tanggung jawab perusahaan terhadap sosial dan lingkungan sekitarnya. Kondisi sosial kepada pemangku kepentingan yang meningkat menjadikan perusahaan memiliki elemen penting yaitu manajemen laba dan pengungkapan CSR [V]. Manajer menghadapi conflict of interest, dengan adanya perbedaan kepentingan yaitu untuk memaksimalkan kompensasi manajemen dan kepentingan shareholders dan stakeholders sehingga untuk menutupi aktivitas perusahaan yang tidak bertanggung jawab dengan baik kepada pihak sosial dan lingkungan mengakibatkan CSR dipandang sebagai retorika perusahaan saja. [D].

Perbedaan pemangku kepentingan dengan pengelola perusahaan mengakibatkan manajer dapat melakukan tindakan manajemen laba. Salah satu cara yang dilakukan oleh manajemen perusahaan untuk melaksanakan prakatik manajemen laba adalah dengan pemilihan standar akuntansi agar informasi laba lebih baik meskipun bukan informasi laba riil. Penerapan metode akuntansi yang dilakukan manajemen dapat dideteksi dengan manajemen laba. Manajemen laba terbagi menjadi dua alat yaitu manajemen laba akrual dan manipulasi aktivitas riil. Sudah banyak penelitian dengan proksi discretionary accrual untuk mendekteksi manajemen laba, maka terdapat proksi lain yaitu classification shifting [E].

[M] dalam teori agensi menyatakan bahwa monitoring cost dalam penerapan corporate governance untuk menyelaraskan kepentingan agen dan principal yaitu dengan melakukan peningkatan proporsi kepemilikan saham yang dimiliki oleh manajemen sehingga menjadi salah satu mekanisme untuk pengendalian atas tindakan oportunistik yang dilakukan manajemen.

Guna untuk mencapai fungsi pengawasan good corporate governance yang efektif maka diperlukan adanya pengungkapan CSR dalam rangka peningkatan nilai perusahaan untuk jangka panjang. Perlu adanaya sinkronisasi antara peran good corporate governance dengan strategi pengungkapan CSR. Menurut [W] Corporate governance dapat dijadikan sebagai sekumpulan mekanisme dalam pengambilan keputusan manajer ketika terdapat pemisahanan antara kepemilikan dan pengelola perusahaan.

Pada penelitian ini manajemen laba sebagai variabel moderasi menggunakan classification shifting, tidak seperti biasanya yang sudah banyak dilakukan menggunakan proksi discretionary accrual. Peran good corporate governance yang terdiri dari kepemilikan isntitusional, komisaris independen dan komite audit apakah mampu melakukan fungsi pengawasan terhadap tindakan manajemen dalam praktik pengungkapan tanggung jawab sosial perusahaan yang diperkuat/diperlemah oleh classification shifting.
Penelitian ini diharapkan memberikan manfaat sebagai bahan evaluasi kinerja oleh perusahaan dan pihak-pihak terkait untuk pencapaian good corporate governance dalam melakukan pengawasan terhadap aktivitas manajemen mengenai manajemen laba dan pengungkapan CSR, dapat digunakan investor dalam pemilihan dan pengambilan keputsan investasi secara tepat.

\section{Kajian Teori}

\section{Corporate Social Responsibility}

[J] menyatakan bahwa pengungkapan CSR merupakan informasi yang dilaporkan oleh perusahaan yang diminta oleh masyarakat sekitar dan pengguna laporan keuangan, informasi tersebut berkaitan dengan hubungan perusahaan dengan masyarakat dan lingkungan sekitarnya, berupa informasi keuangan maupun non keuangan. Informasi biaya dan aktivitas terhadap lingkungan yang dilakukan oleh perusahaan tertuang dalam pengungkapan tanggung jawab sosial guna sebagai alat ukur besarnya indeks pengungkapan informasi terhadap sosial dan lingkungan perusahaan yang disajikan dalam laporan tahunan.

\section{Good Corporate Governance}

Corporate governance merupakan konsep berdasarkan peraturan untuk peningkatan kinerja perusahaan melalui monitoring kinerja dan akuntanbilitas manajemen terhadap stakeholder [G]. Penerapan Corporate governance dalam laporan keuangan agar tercapainya transparasi yang dapat digunakan oleh pengguna laporan keuangan. Dengan adanya transparansi dari manajemen perusahaan yang semakin baik sehingga konsep ini dapat berjalan dengan baik, kemudian berdampak pada peningkatan pertumbuhan ekonomi dan memberikan informasi good news bagi para pengguna.

[R] mengartikan corporate governance sebagai elemen penting dalam perusahaan mengenai investasi dan pembiayaan modal merupakan kunci utama peningkatan pertumbuhan ekonomi dilihat dari aspek keterbukaan perusahaan terhadap pemegang saham.

\section{Classification Shifting}

[P] mendefinisikan manajemen laba menggunakan classsification shifting yaitu adanya unsur kesengajaan manajemen unuk menggeser klasifikasi dari item yang ada dalam laporan laba rugi dan komperehnsif lainnya perusahaan. Penelitian yang dilakukan [P] memfokuskan pada pergeseran klasifikasi yaitu core expense, terdiri dari harga pokok penjualan, beban penjualan dan beban umum \& administrasi ke item khusus. Hal tersebut menunjukkan adanya pergerakan core expense tidak menjadikan laba akhir berubah tetapi terlalu tinggi peningkatan core earnings. Dengan demikian pergeseran klasifikasi tidak mengakibatkan perubahan pada laba bersih tetapi bengaruh terhadap 
shareholder dan stakeholder.

\section{Pengembangan Hipotesis}

Untuk merumuskan hipotesis pada Good Corporate Governance terhadap pengungkapan CSR dimoderasi Manajemen Laba, diperlukan model penelitian sebagaimana disajikan pada Gambar 1.

GAMBAR 1

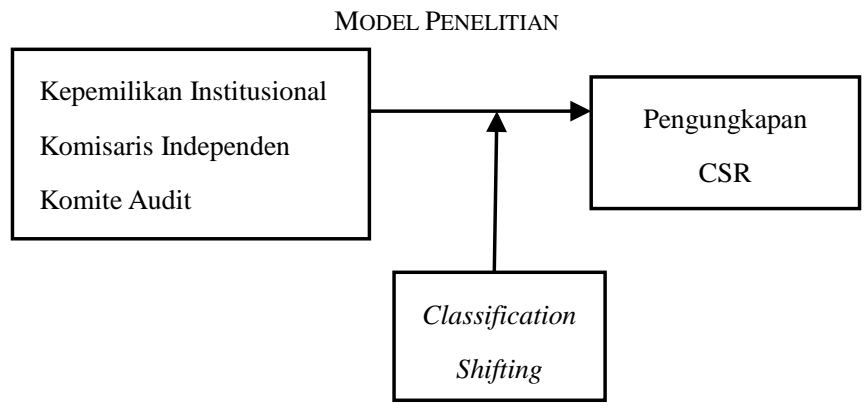

Berdasarkan Agency theory adanya perbedaaan pandangan pihak pemilik dan pengelola dalam memajukan perusahaan sehingga menjadikan konflik diantara pihak tersebut. Dengan adanya kepemilikan institusional sebagai pihak ketiga diharapkan mampu melaksanakan fungsi pengawasan terhadap aktivitas yang dilakukan manajemen. Penelitian hubungan antara ukuran kepemilikan institusional dengan praktik CSR yang dilakukan oleh [DD] menemukan adanya pengaruh signifikan kepemilikan institusional terhadap praktik pengungkapan CSR. [C] menyatakan bahwa nilai kepemilikan institusional yang rendah memberikan pengaruh yang lemah dan nilai kepemilikan yang tinggi memberikan pengaruh positif terhadap pengungkapan CSR, tetapi nilai kepemilikan tidak memberikan pengarug signifikan terhadap perusahaan dengan pengungkapan CSR yang beresiko tinggi. Kepemilikan institusional juga berpengaruh positif terhadap pengungkapan CSR pada perusahan di Cina, hal tersebut didukung oleh pemerintahan, kebijakan dan perusahaan dalam memberikan tanggung jawab kepada lingkungan dan masyarakat sekitar $[\mathrm{X}]$.

\section{H1: Kepemilikan Institusional berpengaruh positif} terhadap pengungkapan CSR

Komisaris independen merupakan pihak ketiga yang mempunyai fungsi pengawasan terhadap kinerja manajemen perusahaan agar tidak melakukan kecurangan dalam menyusun dan menyajikan laporan keuangan perusahaan [BB]. [AA] menyatakan bahwa adanya dewan komisaris independen berpengaruh siginifikan terhadap praktik pengungkapan tanggung jawab sosial. [U] mengemukakan bahwa komisaris independen mampu memberikan nasihat kepada direktur independen agar mempromosikan pembentukan komite CSR dan meningkatkan tercapainya pengungkapan CSR dengan strategi
GRI-IFC. [Y] menyataan bahwa mekanisme good corporate governance, dengan adanya pihak eksternal seperti komisaris independen berpengaruh positif terhadap pengungkapan CSR.

\section{H2: Komisaris Independen berpengaruh positif} terhadap pengungkapan CSR

Struktur dari corporate governance lainnya yaitu komite audit, pembentukan komite audit oleh dewan komisaris untuk membantu dalam pelaksanaan tugas dan fungsi dari dewan komisaris. [K] menyatakan bahwa komite audit mempunyai tanggungjawab terhadap shareholder. $[\mathrm{H}]$ mengemukakan Komite audit mampu memberikan pengaruh positif terhadap pengungkapan CSR pada negara-negara berkembang. Adanya regulator, kebijakan, praktisi dan eksekutif perusahaan lebih memperhatikan reformasi dan penegakan Corporate Governance serta meningkatkan pengungkapan CSR. Menurut $[\mathrm{F}]$ bahwa etika perusahaan yang baik mampu meningkatkan penerapan GCG secara optimal memberikan pengaruh signifikan terhadap pengungkapan CSR.

[Q] mengemukakan salah satu mekanisme dalam penerapan GCG dapat dilihat dari besarnya jumlah komite audit dalam perusahaan, hal tersebut dapat dilakukan dengan fungsi pengawasan yang baik terhadap manajemen untuk mewujudkan asas tanggung jawab kepada masyarakat dan lingkungan sekitarnya, sehingga untuk melaksanakan pengungkapan CSR secara transparan kepada publik. Dengan demikian sebagai bukti yang dilakukan perusahaan mengenai kegiatan perusahaan sesuai dengan prinsip, kaidah dan nilai di masyarakat.

\section{H3: Komite Audit berpengaruh positif terhadap} pengungkapan CSR

Asimetri informasi tidak sama terjadi antara pemilik dan pengelola perusahaan sehingga mengakibatkan perusahaan memberikan sinyal kepada para pihak yang berkaitan. Sinyal tersebut dalam perusahaan dapat berupa informasi baik maupun informasi buruk. [V] mengatakan adanya pengaruh terbalik antar praktek manajemen laba dan pengungkapan CSR. Informasi yang diungkapkan perusahaan bahwa semakin kecil ditemukan adanya manajemen laba maka semakin terbuka pengungkapan CSR. Sedangkan apabila terindikasi bahwa perusahaan melakukan praktik manajemen laba lebih besar maka pengungkapan laporan CSR perusahaan semakin tertutup.

Berdasarkan fungsi pengawasan, kepemilikan institusional yang tinggi dapat meminimalkan terjadinya manajemen laba sehingga semakin terbuka pengungkapan CSR, hal ini dikarenakan kepemilikan institusional merupakan pemegang saham mayoritas sehingga harus turut dalam memonitoring aktivitas manajemen. Namun untuk mencapai kepentingan shareholders dan stakeholders maka kepemilikan 
institusional dapat mendorong manajer untuk melakukan manajemen laba sehingga memperlemah pengungkapan CSR.

H4a: Manajemen Laba memperkuat Pengaruh Positif

Kepemilikan Institusional terhadap Pengungkapan CSR

Sebagai pihak ketiga, komisaris independen dituntut mampu melakukan pengawasan terhadap principal dan agent dalam perbedaan pandangan kemajuan perusahaan. $[\mathrm{N}]$ menyatakan bahwa dalam perusahaan manajemen laba masih ditemukan cukup tinggi sebelum adanya struktur corporate governance. Mnajemen laba menjadi semakin rendah Setelah penerapan struktur corporate governace. Sejalan dengan penelitian [EE] menyatakan bahwa keberadaan komisaris independen sebagai struktur GCG mampu untuk meminimalkan praktik manajemen laba dengan classification shifting.

Komposisi dewan komisaris independen yang tinggi dapat mengurangi praktik manajemen laba sehingga pengungkapan CSR lebih terbuka. Agar terciptanya Good Corporate Governance, tingginya jumlah komisaris independen yang besar dalam perusahaan dapat membantu melaksanakan fungsi monitoring yang efektif. Namun dengan adanya pengungkapan CSR adanya tambahan biaya yang harus dibebankan perusahaan sehingga pihak manajemen berkesempatan untuk melakukan perilaku oportunistik yaitu tindakan manajamen laba.

H4b: Manajemen Laba memperkuat Pengaruh negatif Komisaris Independen terhadap Pengungkapan CSR

Sebagai salah satu struktur corporate governance, komite Audit memiliki fungsi pengawasan terhadap aktivitas manajemen berkaitan dengan tindakan manajemen laba. Adanya auditor eksternal menjadikan peran komite audit akan semakin kuat dalam memenuhi standar audit dan mempertahankan kredibiltasnya. Keesuaian Informasi laporan keuangan dengan standar akuntansi yang berlaku merupakan tugas dan fungsi dari auditor. Dengan adanya koordinasi antara auditor eksternal dan internal audit serta komite audit sehingga pengendalian internal dapat dilakukan secara efektif [O].

Komite audit yang tinggi dapat mengurangi tindakan manajemen laba sehingga pengungkapan CSR lebih, hal ini dimungkinkan karena sifat independensi yang dimilik oleh komite audit sehingga pada setiap pertemuan komite audit secara aktif melakukan pengawasan dan mempertangunggjawabkan hasilnya. Dengan demikian dapat mencegah adanya tindakan yang tidak sesuai dalam manajemen. Terbukanya pengungkapan CSR yang dilakukan perusahaan diharapkan mampu meminimalisir aktivitas manajemen laba.
H4c: Manajemen Laba memperkuat Pengaruh negatif Komite Audit terhadap Pengungkapan CSR

\section{Metode Penelitian}

Jenis penelitian yang dilakukan adalah penelitian korelasional, pendekatan penelitian ini adalah pendekatan kuantitatif. Data pada penelitian ini adalah data sekunder berupa laporan tahunan (laporan keuangan dan laporan CSR) melalui situs Bursa Efek Indonesia (BEI) dan website resmi perusahaan yang diteliti.

Populasi pada penelitian ini adalah perusahaan manufaktur yang terdaftar di BEI tahun 2014 sampai dengan 2018. Rentan waku dipilih karena pada tahun 2014 pertumbuhan perusahaan manufaktur melambat pada kisaran 5\% [B]. Pada tahun selanjutnya terdapat beberapa kasus laporan keuangan yang dialami perusahaan manufaktur seperti PT. Toshiba, PT. Inovisi Infracom, PT. Borneo Lumbung Energi\&Metal. Tahun 2018, [A] dalam Report to the Nations on Occupational Fraud and Abuse mengemukakan kecurangan perusahaan yang dilakukan oleh individu sekitar $78 \%$ dalam pemilihan metode akuntansi, operasi, penjualan, manajemen eksekutif, layanan konsumen, pembelian dan keuangan.

Teknik purposive sampling digunakan dalam pengambilan sampel penelitian ini. Teknik tersebut dipilih karena berdasarkan ciri, sifat, kriteria pokok populasi yang dibutuhkan dalam menghitung proksi variabel penelitian, terutama untuk menghitung classification shifting dan pengungkapan CSR. Kriterianya yaitu sebagai berikut:

1) Perusahaan manufaktur yang terdaftardi BEI pada tahun 2014-2018

2) Perusahaan yang menghasilkan laba selama periode 2014- 2018

3) Terdapat komponen item-item khusus dalam laporan keuangan tahun 2014-2018.

4) Laporan tahunan yang sesuai dengan proksi penelitian.

Uji statistik dalam penelitian ini menggunakan uji asumsi klasik dan uji analisis regresi moderating uji selisih mutlak dengan IBM SPSS 23.

\section{Operasional Variabel}

\section{Pengungkapan CSR}

$$
\begin{aligned}
& \operatorname{CSR} i j=\frac{\sum X i j}{N j} \\
& \operatorname{CSR}^{\mathrm{j}}: \text { Corporate Social Responsibilty Disclosure Index perusahaan } \\
& { }^{X i j} \text { : variabel Dummy }
\end{aligned}
$$


1 = jika item $\mathrm{i}$ diungkapkan, $0=$ jika item $\mathrm{i}$ tidak diungkapkan

$N \hat{j}$ : jumlah item untuk perusahaan j yang relevan, $\mathrm{nj} \leq 78$.

\section{Corporate Governance}

Kepemilikan Institusional

Kep Inst $=\frac{\text { Jumlah Kepemilikan Saham Institusi }}{\text { Jumlah Saham Beredar }} x 100 \%$

\section{Komisaris Independen}

KIndp $=\frac{\text { jumiah } \text { Komisaris dari Luar Perusahoan }}{\text { Jumlah Seluruh } \text { Romisaris Perusahawn }}$

\section{Komite Audit}

Ko Audit $=\frac{\text { Jumlah Rapat Komite Audit }}{4} x 100 \mathrm{~g}$

\section{Manajemen Laba}

$U E \_C E t=$ reported $C E t-$ predicted $C E t$

Reported CEt adalah core earnings yang dilaporkan dalam laporan laba/ rugi pada periode t yang dihitung dari penjualan - HPP - beban penjualan, beban umum \& administrasi/ penjualan (tidak termasuk beban depresiasi dan amortisasi).

Predicted CEt adalah core earnings prediksian dalam tahun $t$, yaitu nilai prediksi dihitung menggunakan predicted value dari persamaan (1) yang diestimasi berdasarkan tahun dan industri [P].

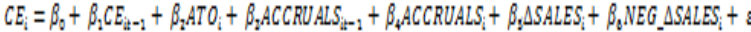

Untuk menghitung classification shifting dengan item khusus=

$$
U E_{-} C E t=\alpha+\mathrm{b} 1 S \mathrm{I}_{\mathrm{i}}+\varepsilon
$$

$S \mathrm{it}_{\mathrm{i}}=$ Special Itemsi $*(-1) /$ Sales

\section{Hasil dan Pembahasan}

TABEL 2

SAMPEL PENELITIAN

\begin{tabular}{|l|c|}
\hline \multicolumn{1}{|c|}{ Keterangan } & Jumlah \\
\hline $\begin{array}{l}\text { Perusahaan Manufaktur yang terdaftar } \\
\text { 2014-2018 }\end{array}$ & 162 \\
$\begin{array}{l}\text { Perusahaan tidak laba tahun 2014-2018 } \\
\text { Tidak adanya informasi item khusus } \\
\text { Data tidak lengkap }\end{array}$ & $(48)$ \\
\hline \multicolumn{1}{|c|}{ Jumlah } & $(40)$ \\
\hline Outlier & 53 \\
\hline \multicolumn{1}{|c|}{ Sampel Penelitian 43 x 5 tahun } & $(10)$ \\
\hline
\end{tabular}

Analisis statistik deskriptif yaitu mendeskripsikan data penelitian tekait distribusi dan perilaku data dikumpulkan dalam penelitian [I].

TABEL 3

STATISTIK DESKRIPTIF

\begin{tabular}{|l|c|c|c|c|c|}
\hline Variabel & $\mathrm{N}$ & Min. & Max & Mean & SD \\
\hline CSR & 215 & 0,380 & 0,5641 & 0,2084 & 0,8435 \\
Kep Inst & 215 & 0,250 & 1,0000 & 0,7031 & 0,1765 \\
Ko Indp & 215 & 0,200 & 0,5800 & 0,4618 & 0,3090 \\
Kom Audit & 215 & 1,000 & 4,5000 & 1,4300 & 0,8610 \\
Manj Laba & 215 & $-1,6178$ & 0,5806 & 0,0010 & 0,1575 \\
& & & & & \\
\hline
\end{tabular}

Setelah dilakukan observasi, diketahui nilai minimum CSR pada perusahaan manufaktur sebesar 0,380 dan nilai maksimum 0,5641. Selanjutnya rata-rata pengungkapan CSR yang dilakukan perusahaan sebesar 0,2084 dan standar deviasi 0,8435.

Pada penelitian ini telah dilakukan uji asumsi klasik yang terdiri dari uji normalitas, uji multikolineritas dan uji heteroskedastisitas. Hasil dari uji tersebut bahwa data berdistribusi normal dengan nilai Asym Sig (2-tailed) sebesar 0,675, data tidak terjadi multikolineritas dengan nilai tolerance $>0,1$ dan nilai VIF $<10$, data juga tidak terjadi heteroskedastisitas dengan nilai alpha lebih besar dari 0,05.

Pengujian hipotesis pada penelitian ini yaitu menggunakan analisis regresi moderating metode selisih mutlak.

TABEL 4

UJI HIPOTESIS

\begin{tabular}{|c|c|c|c|c|}
\hline No & Keterangan & Nilai & & \\
\hline 2. & $\begin{array}{l}\text { Modal Summary } \\
\text { Nilai R } \\
\text { R Square } \\
\text { ANOVA } \\
\text { Nilai F } \\
\text { F Tabel } \\
\text { Sig } \\
\end{array}$ & $\begin{array}{l}0,286 \\
0,082 \\
\\
2,638 \\
2,413 \\
0,012 \\
\end{array}$ & & \\
\hline & & Coefficient & Nilai t & Sig \\
\hline 3. & $\begin{array}{l}\text { Coefficient } \\
\text { Konstanta } \\
\text { Nilai t Tabel } \\
\text { KInst } \\
\text { KIndp } \\
\text { KoAudit } \\
\text { EM } \\
\mid \begin{array}{l}\text { KInst - EM } \\
\text { KIndp - EM } \\
\text { KoAudit - EM }\end{array}\end{array}$ & $\begin{array}{r}0,218 \\
0,010 \\
0,007 \\
0,019 \\
0,004 \\
0,019 \\
-0,004 \\
-0,028 \\
\end{array}$ & $\begin{array}{c}24,259 \\
1,971 \\
1,743 \\
0,694 \\
2,403 \\
0,553 \\
2,227 \\
-0,334 \\
-2,884 \\
\end{array}$ & $\begin{array}{l}0,083 \\
0,489 \\
0,017 \\
0,581 \\
0,027 \\
0,739 \\
0,004\end{array}$ \\
\hline
\end{tabular}

Nilai koefisien korelasi pada tabel diatas adalah 0,286, artinya hubungan antara variabel independen dengan variabel dependen berada pada tingkat hubungan lemah. Pada tabel diatas manajemen laba sebagai variabel moderasi termasuk kategori pure moderate yang artinya bahwa manajemen laba dapat memperkuat/memperlemah pengaruh GCG terhadap pengungkapan CSR, sedangkan manajemen laba sebagai varaibel independen tidak bepengaruh terhadap pengungkapan CSR.

Dilihat dari tabel diatas: nilai signifikansi kepemilikan institusional sebesar 0,083 lebih besar dari $(\alpha)=0,05$ sehingga H1 ditolak; nilai signifikansi komisaris independen sebesar 0,489 lebih besar dari $(\alpha)=0,05$ sehingga $\mathbf{H 2}$ ditolak; nilai signifikansi komite audit 
sebesar 0,017 lebih kecil dari $(\alpha)=0,05$ sehingga $\mathbf{H 3}$ diterima; nilai signifikansi manajemen laba memoderasi kepemilikan institusional sebesar 0,027 lebih kecil dari $(\alpha)=0,05$ sehingga $\mathbf{H 4 a}$ diterima; nilai signifikansi manajemen laba memoderasi komisaris independen sebesar 0,739 lebih besar dari $(\alpha)=0,05$ sehingga H4b ditolak; nilai signifikansi manajemen laba memoderasi komite audit sebesar 0,004 lebih kecil dari $(\alpha)=0,05$ sehingga $\mathbf{H 4 c}$ diterima.

Hasil uji hipotesis 1 menunjukkan kepemilikan institusional tidak berpengaruh terhadap pengungkapan CSR. Pada penelitian ini kepemilikan institusional tidak terbukti memberikan pengaruh positif terhadap pengungkapan CSR. Prosentase tingkat kepemilikan saham institusional tidak menjadi tolak ukur utama terhadap terbukanya pengungkapan CSR. Dengan demikian pemegang saham institusional belum maksimal dalam menjalankan perannya untuk tercipta good corporate governance dan juga tingkat kepekaan terhadap keberlangsungan perusahaan dalam jangka panjang mengenai aktivitas kepedulian terhadap sosial dan lingkungan sebagai pertimbangan utama dalam berinvestasi, di satu sisi pihak institusional mungkin masih berorientasi pada laba perusahaan yang akan didapatkan. Hasil penelitian ini sejalan dengan penelitian $[\mathrm{H}]$ yang menunjukkan hasil bahwa kepemilikan institusional tidak memiliki pengaruh terhadap pengungkapan CSR. Namun, hasil penelitian ini berbeda dengan penelitian [DD] yang menunjukkan bahwa kepemilikan institusional berpengaruh positif terhadap pengungkapan CSR.

Hal tersebut menerangkan bahwa kepemilikan institusional tidak melihat peningkatan dan penurunan nilai pengungkapan CSR, tetapi kepemilikan institusional akan menyesuaikan prosentase kepemilikannya apabila CSR dapat memberikan tingkat yang optimal [L].

Hasil uji hipotesis 2 menunjukkan Komisaris independen tidak berpengaruh siginifikan terhadap pengungkapan CSR. Hal ini disebabkan jumlah komisaris independen yang tidak sebanding dengan jumlah komisaris, sehingga mengakibatkan komisaris independen tidak bisa melaksanakan fungsinya dengan maksimal, terlebih jika dalam pengambilan keputusan berdasarkan hasil suara sehingga komisaris independen tidak mampu memberikan pengaruh dalam pengambilan keputusan yang berdampak pada pengungkapan CSR perusahaan. Hasil penelitian ini sejalan dengan penelitian [Z] menyatakan bahwa komisaris independen tidak memiliki pengaruh signifikan terhadap pengungkapan CSR. Penelitian ini berbeda dengan penelitian [AA] yang menunjukkan bahwa dewan komisaris independen memiliki pengaruh signifikan terhadap praktik pengungkapan CSR.

Meskipun jumlah komisaris independen lebih dari 33\% yaitu sebesar $46 \%$ tetapi belum mampu memberikan pengaruh positif terhadap pengungkapan CSR karena masih minimnya pengawasan terhadap perilaku manajemen.

Hasil uji hipotesis 3 menunjukkan Komite audit berpengaruh positif terhadap pengungkapan CSR. Perusahaan membentuk komite untuk mengawasi kinerja perusahaan berkenaan dengan kualitas laporan keuangan dan reviu pengendalian internal, dan juga pengawasan terhadap pengungkapan kegiatan CSR perusahaan sebagai bentuk kepedulian perusahaan terhadap sosial dan lingkungan. Dengan adanya pertemuan yang diadakan komite audit mampu menghasilkan pengungkapan CSR yang lebih terbuka. Penelitian ini sejalan dengan penelitian $[\mathrm{N}]$ menyatakan adanya pengaruh positif komite audit terhadap pengungkapan CSR.

Hasil uji hipotesis 4a menunjukkan manajemen laba memoderasi pengaruh positif kepemilikan institusional terhadap pengungkapan CSR. [Q] mengemukakan bahwa kepemilikan institusional berpengaruh positif terhadap pengungkapan CSR. Kebijakan yang disusun oleh pemerintah terkait CSR untuk melakukan pengawasan terhadap perilaku manajemen perusahaan dalam pelaksanaan kebijakan dengan baik sehingga perusahaan dipandang baik oleh masyarakat agar tidak terjadi kendala apabila perusahaan tidak mempedulikan siklus perusahaan yang dapat mempengaruhi lingkungan sekitarnya. Akan tetapi, pengungkapan CSR dijadikan tameng sebagai alat yang digunakan perusahaan sebagai pengalih perhatian untuk menutupi praktik manajemen laba. Dengan kualitas laba dan adanya pengungkapan CSR yang baik, maka hal tersebut sebagai strategi agar investor semakin yakin untuk tetap berinvestasi pada perusahaan. Pengungkapan CSR juga digunakan untuk menjaga hubungan dengan stakeholders demi kelangsungan hidup perusahaan.

[T] menyatakan bahwa manajemen perusahaan semakin aktif dalam aktivitas tindakan manajemen laba melalui kebijakan CSR maka akan meningkatkan nama baik dan mendapatkan dukungan dari publik dan stakeholder. Manajemen laba dilakukan untuk menutupi tindakan opportunistik manajemen sehingga manajemen laba mampu memperkuat pemegang saham intitusional agar pengungkapan CSR lebih terbuka demi kepentingan pemegang saham terkait laba perusahaan yang akan didapatkan. Teori legitimasi menyebutkan bahwa hubungan antara perusahaan dengan masyarakat dapat mempertahankan kelangsungan hidup perusahaan. Dengan demikian perusahaan harus melakukan aktivitas CSR nya, masyarakat akan semakin percaya terhadap perusahaan apabila semakin banyak CSR yang dilakukan oleh perusahaan. Tetapi hal ini juga kesempatan bagi manajemen untuk menutupi manajemen laba yang dilakukan.

Hasil uji hipotesis $4 \mathrm{~b}$ menunjukkan manajemen laba 146 | Jurnal Akuntansi, Ekonomi dan Manajemen Bisnis | Vol. 8 No.2, December 2020, 141-149 | E-ISSN: 2548-9836 
tidak memoderasi pengaruh negatif komisaris independen terhadap pengungkapan CSR. Penelitian ini sejalan dengan penelitian [Q] menunjukkan hasil bahwa komisaris independen tidak berpengaruh signifikan terhadap pengungkapan CSR. Komisaris independen merupakan komisaris yang terpisah dari direksi maupun komisaris dependen, tidak berkaitan dengan aktivitas bisnis perusahaan. Komisaris independen mempunyai tanggung jawab utama untuk dapat diterapkannya prinsip tata kelola perusahaan yang baik melalui pengawasan terhadap direksi secara efektif sehingga memberikan nilai tambah bagi perusahaan.

Namun pada kenyataannya, adanya praktik manajemen laba tidak mampu memperkuat pengaruh negatif komisaris independen terhadap pengungkapan CSR. Hal ini menerangkan bahwa jumlah komisaris independen pada penelitian ini rata-rata $46 \%$, walaupun lebih tinggi dari $33 \%$ namun bukanlah menjadi faktor utama dari pengawasan yang efektif terhadap manajemen perusahaan. Akan tetapi, keberadaan komisaris independen terhambat oleh tindakan manajemen yang didukung oleh pemegang saham mayoritas sehingga dalam memonitoring manajemen perusahaan tidak optimal. Di satu sisi, komisaris indenpenden adalah pihak luar yang terbebas dari hubungan perusahaan dan juga bukan pembuat kebijakan maupun pengambilan keputusan sehingga tidak mampu menpengaruhi pengungkapan CSR.

Hasil uji hipotesis 4c menunjukkan manajemen laba memoderasi pengaruh negatif komite audit terhadap pengungkapan CSR. Dewan komisaris membentuk komite audit untuk membantu melaksanakan fungsi pengawasan terhadap manajemen perusahaan. Komite audit memiliki tugas yang menghubungkan kepentingan pemegang saham dan dewan komisaris dengan manajemen untuk penanganan permasalahan dalam pengendalian. Tujuan dibentuknya komite audit dalam perusahaan adalah untuk meningkatkan efektivitas, akuntanbilitas, transparasi dan objektivitas dewan direksi dan dewan komisaris sehingga dapat memberikan penilaian kinerja keuangan perusahaan, peningkatan independensi dan objektivitas auditor internal saat mereviu laporan keuangan untuk dilakukan perbaikan, memperkuat posisi auditor eksternal, memperbaiki kualitas pelaporan keuangan agar tingkat kepercayaan investor terhadap perusahaan semakin meningkat [Y].

Penelitian [Q] menunjukkan bahwa ukuran komite audit memiliki pengaruh negatif terhadap pengungkapan CSR. Hasil tersebut menjelaskan bahwa komite audit mampu berperan dalam memberikan pengaruh akuntabilitas dari strategi implementasi pengungkapan CSR. Hal ini dikarenakan komite audit yang mempunyai sifat independen, pada setiap pertemuan komite audit melakukan pengawasan dengan aktif dan hasil dapat dipertanggungjawabkan.
Tindakan aktif yang dilakukan manajemen terkait manajemen laba untuk mendapatkan dukungan dari publik dan stakeholder dengan adanya kebijakan CSR sehingga meningkatkan citra perusahaan [T]. Meskipun manajemen laba dilakukan oleh perusahaan, tetapi komite audit tetap berpegang pada tugas dan fungsinya memonitoring tindakan manajemen agar terwujud tata kelola yang baik dan juga mengawasi dalam pelaporan pengungkapan CSR yang transparan dan akuntanbel sehingga manajemen laba dapat diminimalisir dengan adanya komite audit.

\section{Simpulan dan Saran}

Hasil penelitian ini menunjukkan bahwa kepemilikan institusional dan komisaris independen tidak berpengaruh terhadap pengungkapan CSR, sedangkan komite audit berpengaruh positif terhadap pengungkapan CSR. Manajemen laba memperkuat pengaruh positif kepemilikan institusional dan pengaruh negatif komite audit terhadap Pengungkapan CSR. Namun manajemen laba tidak memoderasi komisaris independen terhadap pengungkapan CSR.

Keterbatasan dalam penelitian ini adalah jumah $R$ Square dalam penelitian ini sangat rendah untuk variabel yang diteliti. Komisaris independen tidak memberikan pengaruh terhadap pengungkapan CSR maupun saat dimoderasi manajemen laba. Penelitian selanjutnya disarankan menggunakan proksi lain untuk komisaris independen yang lebih tepat. Penelitian selanjutnya dapat menggunakan variabel seperti kinerja keuangan, direktur independen, budaya organisasi, kepemilikan volatilitas pengembalian saham dan lain-lain yang dapat mempengaruhi pengungkapan CSR.

\section{Daftar Pustaka}

A. Association of Certified Fraud Examiners (ACFE). (2018). Report to the Nations on Occupational Fraud and Abuse

B. Badan Pusat Statistik. (2014). Pertumbuhan Perusahaan Manufaktur Melambat. Diakses pada 16 Mei. http://www.kemenperin.go.id/pertumbuhan-man ufaktur-melambat.

C. Buchanan, B., Cao, Cathy X., Chen, C. (2018). Corporate social responsibility, firm value, and influential institutional ownership. Journal of Corporate Finance, 07.004.

D. Chih, HI., Shen, CH. dan Kang, FC. (2008). CSR, Investor Protection and Earning Management: Some International Evidence. Journal of Business Ethics, Vol. 10, No.79, pp.179-198. 
E. Debbianita., Veronica, S.S, dan Adhariani, D. (2016). Manajemen Laba Menggunakan Classification Shifting dan Kualitas Audit. Jurnal Keuangan dan Perbankan Vol. 20, No.2, pp. 186-194.

F. ElGammal, Walid., ElKassar, Abdul Nassar., Messarra, Leila Canaan. (2018). Corporate ethics, governance and social responsibility in MENA countries. Manajement Decision, Vol.56, Issue:1, pp.273-291.

G. FCGI. (2001). Seri Tata Kelola Perusahaan (Corpotare Governance) Edisi ke 2. Jakarta.

H. Garas, Samy., Elmassah, Suzanna. (2018). Corporate governance and corporate social responsibility disclosures The case of GCC countries. Critical Perspective On International Bussiness, 1742-2043.

I. Ghozali, I. (2017). Aplikasi Analisis Multivariate dengan Program SPSS. Edisi keempat. Semarang: Badan Penerbit Universitas Diponegoro.

J. Guthrie, J. and Mathews, M.R. (1985). Corporate social accounting in Australasia. Research in Corporate Social Performance and Policy Vol. 7, pp.251-277.

K. Haldar, PK., dan Mishra, L. (2015). The Changing Facets of Corporate Governance and Corporate Social Responsibility in India and their Interrelationship. Information Management and Business Review. Vol.7 No.3, pp.6-16.

L. Harjoto, Maretno., Hoje Jo., Kim Yongtae. (2015). Is Institutional Ownership Related to Corporate Social Responsibility? The Nonlinear Relation and Its Implication for Stock Return Volatility. $J$. Bus. Ethics Springer Science + Bussiness Media Dordrecht.

M. Jensen, C M., dan Meckling, W H. (1976). Theory of the Firm: Managerial Behavior, Agency Cost and Ownership Structure. Journal of Financial economic, October, Vol. 3 No.4, pp.305-360.

N. Loekita, VKK., dan Sukartha, IM. (2016). "Pengaruh GCG pada Manajemen Laba Perusahaan Pengakuisisi Sebelum Merger dan Akuisisi", E-Jurnal Akuntansi Universitas Udayana, Vol.2, No.14, pp.587-614.

O. Lin, S., M. Pizzini, M. Vargus, and I.R. Bardhan. (2011). The Role of The Internal Audit Function in The Disclosure of Material Weaknesses. The Accounting Review, Vol. 86, No.1, pp.69-86.

P. Mc Vay, SE. (2006). Earnings Management Using Classification Shifting: An Examination of Core Eranings and Special Items", The accounting Review, Vol.81 No.3. pp. 501-531.
Q. Nugroho, M.N., Yulianto, A. (2015). Pengaruh Profitabilitas Dan Mekanisme Corporate Governance Terhadap Pengungkapan CSR Perusahaan Terdaftar JII 2011-2013", Accounting Analysis Journal, Vol.4, No. 1, pp.1-10.

R. Organization for Economic Coorperation and Development/ OECD. (2015). G20/OECD Principles of Corporate Governance.

S. Peraturan Bapepam No. KEP-431/BL/2012 tentang Penyampaian Laporan Tahunan Emiten atau Perusahaan Publik.

T. Prior, D., J. Surroca and Tribo J.A. (2008). Are socially responsible managers really ethical? Exploring the relationship between earnings management and corporate social responsibility. Corporate Governance: An International Review, Vol. 16, No. 3, pp.443-459.

U. Sanchez, I.M. Corcia., Miranda, M.E. Gomes., David F., Ariza, L. Retriguez. (2019). Board independence and GRI-IFC performance standards: The mediating effect of the CSR committee. Journal Of Cleaner Production 225 (2019) pp. 554-562.

V. Scholtens, B., dan Kang, FC. (2013). Corporate Social Responsibility and Earning Manangement: Evidence from Asian Economics. Corporate Social Responsibility and Environmental Management. Vol. 20, No.3 , pp.66-87 .

W. Setiyarini., Purwanti, L. (2011). Mekanisme Good Corporate Governance, Manajemen Laba dan Kinerja Perusahaan (Studi Empiris pada Perusahaan yang Terdaftar di BEI). Jurnal Ilmiah Akuntansi dan Humanika Vol.1 No.1.

X. Shahab, Yasir., Chengang Ye. (2018). Corporate social responsibility disclosure and corporate governance: empirical insights on neo-institutional framework from China. Int. J. Discl Gov. Macmillan Publisher. Ltd, Part Of Springer Nature, Vol.15 Issue.2, pp.87-103.

Y. Soewarno, Noorlailie. (2018). The effect of good corporate governance mechanism and corporate social responsibility on financial performance with earnings management as mediating variable. Asian Journal of Accounting Research, 2443-4175 .

Z. Suhardjanto, Djoko., Purwanto., Sari, Kartika., Setiany, Erna. (2018). Corporate governance and social disclosure: a comparative study of listed hospitality industries in South East Asia", Int. J. Trade and Global Market, Vol 11, No.1, pp. 238-253.

AA. Sulastini, Sri. (2007). Pengaruh Karakteristik Perusahaan Terhadap Social Disclosure. 
Perusahaan Manufaktur yang telah Go Public. Universitas Diponegoro.

BB. Sulisyanto, HS. (2008). Manajemen Laba, Teori dan Empiris. Jakarta: Grasindo.

CC. Undang-Undang No. 47 Tahun 2012 tentang Tanggung Jawab Sosial dan Lingkungan Perseroan Terbatas. Lembaran Negara RI Tahun 2012. Sekretariat Negara Jakarta.

DD. Yao, Shujie, Wang, Jianling dan Song, Lin. (2011). Determinants of Social Responsibility Disclosure by Chinese Firms. Dalam Discussion Paper. Nothingham: University of Nothingham.

EE. Zalata, A., and Roberts, C. (2016). Internal Corporate Governance and Classification Shifting Practices: An Analysis of U.K Corporate Behavior. Journal of Accounting, Auditing \& Finance. Vol. 3 No.1, pp. 51-78. 